\title{
Sod-Based Peanut/Cotton Rotation-Soil Health Part 1: Root Depth, Earthworms and Soil Water Infiltration'1
}

\author{
T. W. Katsvairo, D. L. Wright, J. J. Marois, D. Hartzog, P. J. Wiatrak and J. R. Rich ${ }^{2}$
}

\section{Introduction}

When included in the traditional peanut/cotton rotation, perennial grasses can greatly improve soil health. Perennial grasses can also be grown under soil conditions that are not suitable for many agronomic crops and can be used to improve soil conditions before less vigorous annual crops are grown. In IFAS/EDIS publication SS-AGR-126 Sod/Livestock based Peanut/Cotton Production Systems: Why We Recommend It!

(http://edis.ifas.ufl.edu/AG258), we gave an over-view of why growers should adopt the sod based peanut/cotton cropping system in place of the traditional peanut/cotton rotation. In this article we report on the importance of perennial grasses on soil health and we focus on root growth, earthworm population densities and soil water infiltration.

\section{Rooting Depth}

Most coastal soils are impacted by a natural compaction layer starting at 6 inches deep and extending through to 14 inches soil depth. The compaction layer limits root growth to shallow depths and consequently make crops more prone to moisture stress. Perennials, including bahiagrass and Bermuda grass, develop a large, deep and extensive root system which can grow through the compaction layer. When the sod is killed, the roots decay and leave root channels. The roots of the subsequent crops can grow through the channels left behind by the sod to reach deeper soil depths. Results from our experiments in Quincy, FL show larger crown root diameter, root area and total length for cotton grown after bahiagrass compared to cotton in the conventional peanut/cotton rotation (Table 1).

\section{Effect on Irrigation Frequency}

Perennial grasses including bahiagrass and Bermuda grass can reduce the need for irrigation in the following crop. Research conducted in Alabama shows that with plant rooting depth of 6 inches, plants will experience water stress after only 3 days without rainfall. However, if the rooting depth was 60 inches, the plant would not experience water stress until 30 days after rainfall (Table 2). Cropping

1. This document is SS-AGR-124, one of a series of the Agronomy Department, Florida Cooperative Extension Service, Institute of Food and Agricultural Sciences, University of Florida. Original publication date July 2006. Visit the EDIS Web Site at http://edis.ifas.ufl.edu.

2. T. W. Katsvairo, crop and soil scientist; D. L. Wright, professor; J. J. Marois, professor; D. Hartzog, professor, Auburn University; P. J. Wiatrak, agronomist; and J. R. Rich, professor; North Florida Research and Education Center--Quincy, FL; Florida Cooperative Extension Service, Institute of Food and Agricultural Sciences, University of Florida, Gainesville, FL 32611.

The use of trade names in this publication is solely for the purpose of providing specific information. UF/IFAS does not guarantee or warranty the products named, and references to them in this publication does not signify our approval to the exclusion of other products of suitable composition.

The Institute of Food and Agricultural Sciences (IFAS) is an Equal Opportunity Institution authorized to provide research, educational information and other services only to individuals and institutions that function with non-discrimination with respect to race, creed, color, religion, age, disability, sex, sexual orientation, marital status, national origin, political opinions or affiliations. U.S. Department of Agriculture, Cooperative Extension Service, University of Florida, IFAS, Florida A. \& M. University Cooperative Extension Program, and Boards of County Commissioners Cooperating. Larry Arrington, Dean 
systems that increase rooting depth and reduce the need for irrigation are essential for water conservation and water use efficiency.

\section{Organic Matter}

Soils in the southeastern U. S. are generally less fertile and have lower organic matter (OM) compared to those in much of the U.S. We have further degraded these delicate soils by continuous row cropping and tillage. When the land was first cleared and plowed from forests and native prairie grasses, the soil OM content near the surface was around 4\% and to date the OM content of these soils is $0.5-1 \%$ as a result of continuous cropping. Perennial grasses such as bahiagrass and Bermuda grass can increase the organic matter content of the soils. Organic matter improves soil aggregation, water infiltration, reduces soil erosion, acts as a storehouse for slow release of nutrients and provides substrate to be used by soil fauna including the wide array of microbes and earthworms. Soil OM also enables soils to absorb compaction from tillage and harvest equipment as a result of less compaction.

\section{Earthworms}

Farmers should like to see earthworms in their fields because they are very beneficial to soil health. Rotation with bahiagrass greatly increases earthworm population densities. As is the case with the roots of perennial crops, earthworm burrows also provide preferential pathways for root elongation and soil water infiltration. In fact, sometimes earthworm channels are the only way for roots to reach lower horizons in soils with compacted layers. Studies from Quincy, FL and Headland, AL have shown earthworm channels through the compaction layer. Furthermore, we have observed stunning images of roots growing through the compaction layer from either earthworm burrows or old root channels (Figures 1 and 2).

Earthworms also have other benefits to soil health, including increasing aggregate stability, water holding capacity, aeration, reducing surface crusting, incorporating organic residues and amendments into the soil and recycling plant nutrients.

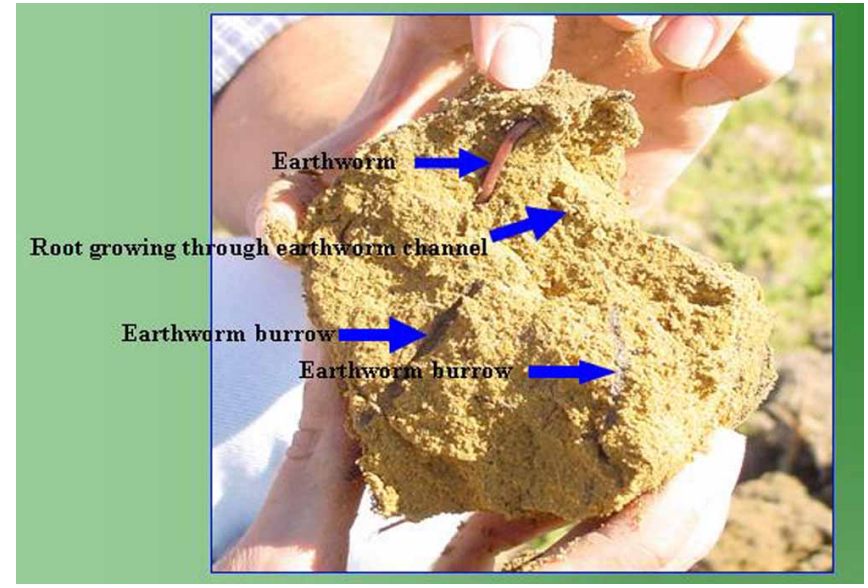

Figure 1. A soil clod showing an earthworm, earthworm burrows, and roots growing through earthworm channels in the natural soil compaction layer in Florida. The soil clod was dug from a sod-rotated field.

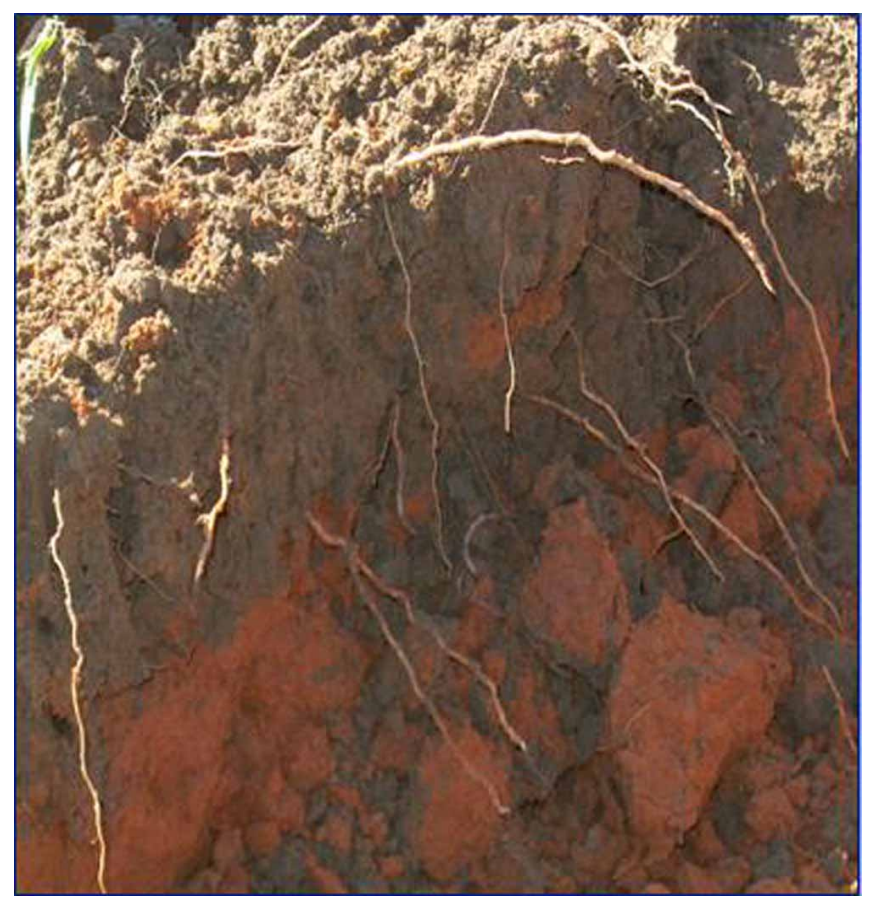

Figure 2. Earthworms and cotton roots in the natural soil compaction layer in bahiagrass-rotated cotton in Florida.

\section{Soil Water Infiltration Rates}

We have observed greater infiltration rates in sod-based peanut/cotton cropping systems compared to the traditional peanut/cotton rotation. High infiltration rates are important because they reduce soil erosion, and subsequently increase soil moisture for plants. Perennial grasses and earthworms both create channels in the soil which increase infiltration rates. Furthermore, we have observed positive correlations between earthworm densities and 
infiltration rates. Table 3 shows infiltration rates in inches per minute at Quincy, FL. The experiment to determine soil water infiltration can be easily done by farmers.

\section{Conclusion}

We recommend growers adopt the sod-based peanut/cotton cropping systems in place of the traditional peanut/cotton rotation because the sod rotation has numerous advantages on soil health to include increased rooting depth, greater earthworm population densities and higher infiltration rates. Complete details on the sod rotation including the effect on plant health, weeds, diseases, pests, yield and economics are also available on our Web site http://nfrec.ifas.ufl.edu/sodrotation.htm and also in our other publication on this site and elsewhere. 
Sod-Based Peanut/Cotton Rotation-Soil Health Part 1: Root Depth, Earthworms and Soil....

Table 1. Cotton crown root diameter, area, length, and biomass at maturity for cotton under conventional and bahiagrass rotation in Florida.

\begin{tabular}{||l|c|c|c|c||}
\hline Rotation & $\begin{array}{c}\text { Crown } \\
\text { Diameter (in) }\end{array}$ & Area (in ${ }^{2}$ ) & $\begin{array}{c}\text { Length } \\
\text { (in) }\end{array}$ & $\begin{array}{c}\text { Biomass } \\
\text { (lbs/acre) }\end{array}$ \\
\hline Bahia-Bahia-Peanut-Cotton & $0.9 \mathrm{~b}$ & $13.5 \mathrm{~b}$ & $250 \mathrm{~b}$ & $1844 \mathrm{a}$ \\
\hline Cotton-Peanut-Cotton-Cotton & $0.6 \mathrm{a}$ & $8.9 \mathrm{a}$ & $179 \mathrm{a}$ & $1035 \mathrm{~b}$ \\
\hline \hline
\end{tabular}

Table 2. Days without plant water stress following rainfall for different rooting depths.

\begin{tabular}{|c|c||}
\hline \hline $\begin{array}{c}\text { Rooting depth } \\
\text { (inches) }\end{array}$ & $\begin{array}{c}\text { Days without water stress } \\
\text { following rainfall }\end{array}$ \\
\hline 6 & 3 \\
\hline 9 & 5 \\
\hline 12 & 6 \\
\hline 24 & 12 \\
\hline 36 & 18 \\
\hline 48 & 24 \\
\hline 60 & 30 \\
\hline $\begin{array}{l}\text { The available water was 0.4 inches per 4.7 inches of soil, and the } \\
\text { evapotranspiration 0.33 inches/day-1. (Atter Elkins, et al. 1977) }\end{array}$ \\
\hline \hline
\end{tabular}

Table 3. Soil water infiltration rates under conventional and bahiagrass-rotated cotton in Florida.

\begin{tabular}{||l|c||}
\hline \hline Rotation & ------in/min ----- \\
\hline & Surface \\
\hline Bahia-Bahia-Peanut-Cotton & $0.73 \mathrm{a}$ \\
\hline Cotton-Peanut-Cotton-Cotton & $0.12 \mathrm{~b}$ \\
\hline & $\begin{array}{c}\text { Compacted } \\
\text { zone }\end{array}$ \\
\hline Bahia-Bahia-Peanut-Cotton & $0.50 \mathrm{a}$ \\
\hline Cotton-Peanut-Cotton-Cotton & $0.06 \mathrm{~b}$ \\
\hline \hline
\end{tabular}

